\author{
E. CHALMIN ${ }^{1,2,} *$ \\ C. VIGNAUD ${ }^{1,3}$ \\ H. SALOMON ${ }^{1}$ \\ F. FARGES ${ }^{2,4}$ \\ J. SUSINI ${ }^{5}$ \\ M. MENU ${ }^{1}$
}

\title{
Minerals discovered in paleolithic black pigments by transmission electron microscopy and micro-X-ray absorption near-edge structure
}

\author{
${ }^{1}$ Centre de Recherche et de Restauration des Musées de France, UMR 151(CNRS), \\ 14, quai François Mitterrand, 75001 Paris, France \\ 2 Laboratoire des Géomatériaux, Université de Marne la Vallée, 5 Bd R. Descartes, \\ Champs sur Marne 77454 Marne la Vallée Cedex 2, France \\ ${ }^{3}$ Laboratoire Interfaces et Systèmes Electrochimiques, 4, place Jussieu, 75252 Paris Cedex 05, France \\ ${ }^{4}$ Department of Geological and Environmental Sciences, Stanford University, Stanford, \\ CA 94305-2115, USA \\ ${ }^{5}$ ESRF, 38043 Grenoble, France
}

\section{Received: 5 December 2005/Accepted: 12 December 2005 Published online: 3 March 2006 • (C) Springer-Verlag 2006}

ABSTRACT Analysis of archeological materials aims to rediscover the know-how of prehistoric men by determining the nature of the painting matter, its preparation mode, and the geographic origin of its raw materials. The preparation mode of the painting matter of the paleolithic rock art apparently consisted of mixing, grinding, and also heat-treatment.

In this study, we focus on black pigments and more particularly manganese oxides. Using the combined approach of transmission electron microscopy (TEM) and Mn $K$-edge Xray absorption near-edge structure (XANES) spectroscopy, we analyzed a variety of archeological black painted samples. The studied pigments arise from the caves of Ekain (Basque country, Spain), Labastide and Gargas (Hautes-Pyrénées, France). In addition, a black "crayon" (i.e., a "pen") from the cave of Combe Saunière (Dordogne, France) was also investigated. From the analysis of these painting matters, several unusual minerals have been identified as black pigment, such as manganite, groutite, todorokite and birnessite. These conclusions enable us to estimate the technical level of paleolithic artists: they didn't use heat-treatment to prepare black painting matter. Consequently, the unusual mineralogy found in some of these pigments suggests that some of the manganese ores are coming from geological settings that are sometimes relatively far away from the Dordogne and Basque region such as in Ariège (central-oriental Pyrénées).

PACS 68.37Lp; 61.10Ht; $83.80 \mathrm{Nb}$

1

\section{Introduction}

Since the recognition of rock art in 1902 in southwestern Europe [1], several questions were raised regarding the geographic (or geological) origins of the pigments, the preparation mode and the painting methods. Elemental and structural analysis were conducted to determine the mineralogical nature of these pigments: red is due to hematite

Fax: +334-76-882785, E-mail: chalmin_emilie@yahoo.fr

*Present adress: ESRF, BP220, 38043 Grenoble cedex, France
( $\alpha-\mathrm{Fe}_{2} \mathrm{O}_{3}$ ), yellow to goethite $(\alpha-\mathrm{FeOOH})$ and black to charcoal or manganese oxides/hydroxides. Several studies [2-5] have evidenced various painting preparation modes performed to enhance the pigments properties (such as color, texture, adhesion and layout). The preparation of the painting matter could be obtained by several steps such as mixing with an extender (clay, calcite, quartz, potassium feldspar, etc.) or a binder (water, animal fat or vegetable oil), grinding or heattreatment. Actually, heat-treated red pigments, coming from the dehydration of goethite, have been identified mainly in funeral and settlement context [6].

The purpose of this article is to present the minerals newly identified in several archeological samples coming from various caves or sites. The rock art painting matter was sampled on two figures of the cave of Ekain (Spanish Basque country) and on two negative hands of the cave of Gargas (HautesPyrénées, France). The others samples come from natural deposits inside the cave of Labastide (Hautes-Pyrénées, France) and from black blocks (a "crayon"; or a "pen") in settlement context (Combe Saunière in Dordogne, France).

\subsection{The archeological context}

The site of Ekain (Basque Country, Spain) is a decorated cave representing mainly horses, corresponding to the Magdalenian culture (industry of the European Upper Paleolithic, circa 16500-12500 B.P., before present, before 1950). The black pigment used in the majority of these paintings is charcoal. Nevertheless, one painting of horse and another one of two bears (Fig. 1) were realized with manganese oxide. One aim of this study is to know if paleolithic men used the black natural deposit inside the cave as pigment ore to realize these paintings.

The cave of Gargas (Hautes-Pyrénées, France) corresponding to the Gravettian culture (from 28000 to 22000 B.P.) is famous for its negative hands covering the walls (up to 231). Their color is black and red in most cases, but ochre, bistre and white were also painted. A physicochemical study of the painting matter of some hands showed they were made at different times [7]. 


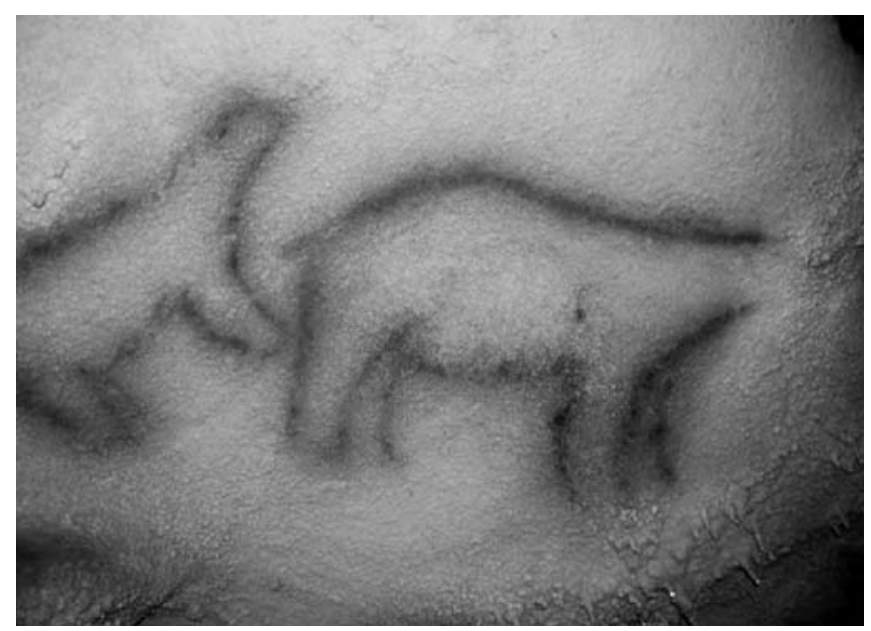

FIGURE 1 The two bears from the cave of Ekain (Basque Country, Spain) Société des Sciences Aranzadi, Altuna, J

The Labastide cave, located in the Hautes-Pyrénées (France), is a Magdalenian settlement site (circa 1650012500 B.P.), adorned with rock paintings and engravings. The site concealed several movable art objects representing birds, ibexes, horses and buffaloes. In addition, there is the discovery of the presence of black deposits on the cave floor which could constitute raw material that could have been used as black pigment [8].

The cave of Combe Saunière (Dordogne, France) was found to be a hunting stop and witnessed repetitive and prolonged settlements from the Mousterian (circa 58000 B.P.) to the Magdalenian culture (circa 12500 B.P.) [9]. The settlement of Combe Saunière does not present any rock art figures, but a large quantity of blocks of pigment, dark and red as well, which may suggest painting activities (coloring animal or human skin, painting wood or bark, preparations for other sites with rock art) or other utilities still unknown. Despite the fact that there is no rock painting, several fragments of red, yellow and black pigment were discovered in the most preserved levels, the Solutrean (18 000-17 000 B.P.) levels. Only one black block shows some evidence of utilization, traces of rubbing against a hard rock to obtain coloring powder (Fig. 5a).

\section{2}

\section{Structural identification of manganese oxides/hydroxides}

Different varieties of manganese oxides/hydroxides are known, depending of their chemical composition, oxidation degree (II, III, IV or mixed) and crystalline structure. They are made up of octahedral units $\left[\mathrm{MnO}_{6}\right]$, arranged as tunnels of various sizes $\left(1 \times 1\left[\mathrm{MnO}_{6}\right]\right.$, structural octahedral unit, $1 \times 2,2 \times 2,3 \times 3$ ). The bigger tunnel contains water molecules and charge-compensating cations such as $\mathrm{Ba}^{2+}$, $\mathrm{K}^{+}$and $\mathrm{Ca}^{2+}$ [10]. Two main families of these compounds are considered in this study: the simple and the composite manganese oxides (Fig. 2). Only some of these minerals have already been identified in prehistoric black pigments: pyrolusite $\beta-\mathrm{MnO}_{2}[4,11]$, hollandite $\mathrm{Ba}\left(\mathrm{Mn}^{[\mathrm{IV}]}, \mathrm{Mn}^{[\mathrm{III}]}\right)_{8} \mathrm{O}_{16} \bullet$ $x \mathrm{H}_{2} \mathrm{O}$ [12,13], bixbyite $\mathrm{Mn}_{2} \mathrm{O}_{3}[14,15]$ and romanechite $\left(\mathrm{Ba}, \mathrm{H}_{2} \mathrm{O}\right)_{2}\left(\mathrm{Mn}^{[\mathrm{III}]}, \mathrm{Mn}^{[\mathrm{IV}]}\right)_{5} \mathrm{O}_{10}[16]$.

To provide more information about painting preparation through potential heat-treatment procedures, the behavior of

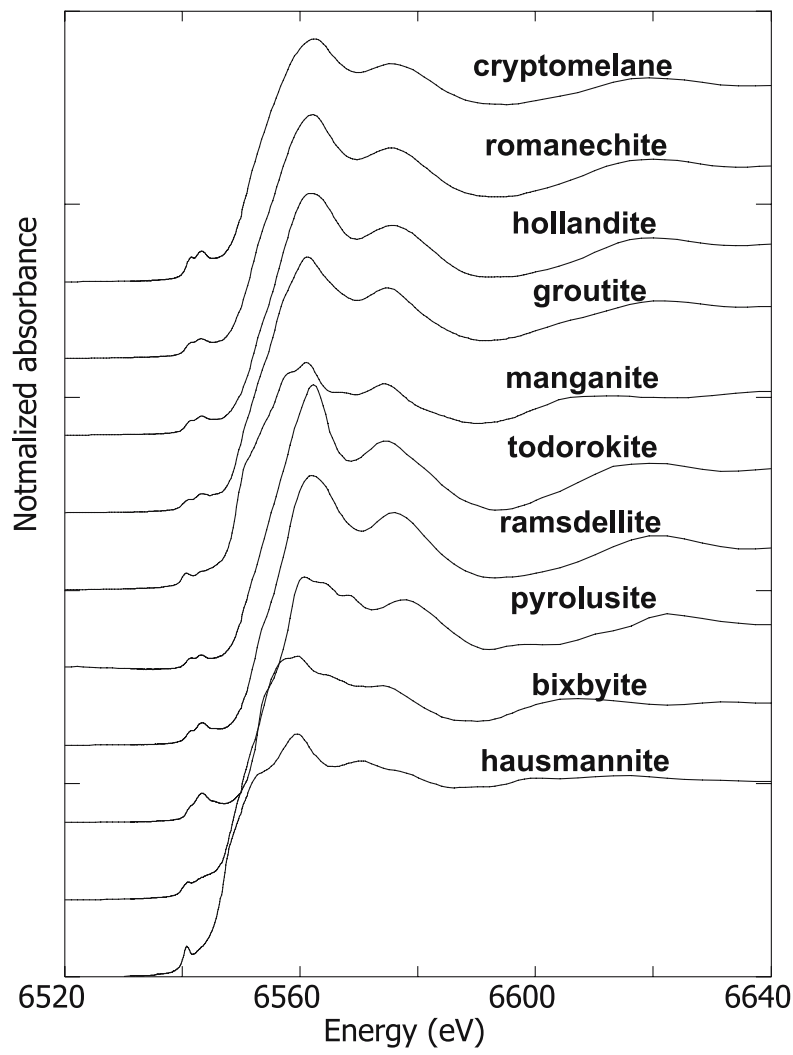

FIGURE 2 Manganese $K$-edge normalized spectra for various manganese oxides (data collected at SSRL, beamline 11-2)

different manganese oxides during heat-treatment has been studied on natural reference minerals [13] and compared to the archeological samples.

\section{Experimental methods \\ 2.1 SEM and TEM methodology}

The samples could be observed by scanning electron microscopy (SEM) without any preparation or after being included in epoxy to visualize the stratigraphy of painting layers. The observations were carried out on a Philips XL 30 $\mathrm{CP}$ instrument (operating voltage $20 \mathrm{kV}$; C2RMF).

The various manganese oxides were characterized by transmission electron microscopy (TEM) at a nanometric scale. Samples were first ground in an agate mortar. Then, the powders were dispersed ultrasonically in ethanol. Finally, a droplet of that mixture was deposited onto a carbon-coated gold grid. This procedure requires a very small quantity of powder (1 mg), compatible with the available samples of rock art painting. TEM observations were carried out on the Jeol 2000FX instrument (operating voltage $200 \mathrm{kV}$ ), equipped with an X-ray analysis system (Oxford, ISIS) at the Laboratoire de Chimie Métallurgique des Terres Rares (CNRS, Thiais, France).

\subsection{XAFS data collection and normalization}

Mn $K$-edge XANES spectra for model compounds and archeological pigments were collected under high resolution conditions $(\sim 0.6 \mathrm{eV}$ at SSRL (Stanford, USA) using 
a beamline 11-2, $\mathrm{Si}(220)$ double-crystal monochromator, with a $0.3 \mathrm{~mm}$ vertical height for the slits before and after the monochromator. Pre-edge features were collected using $0.1 \mathrm{eV}$ steps whereas the main edge crests were collected with $0.3 \mathrm{eV}$ steps to $300 \mathrm{eV}$ above the absorption edge. The spectra of various manganese oxides are presented in Fig. 2.

In parallel, micro-XANES spectra were collected in order to map at the micron scale, the manganese speciation. $\mathrm{Si}$ (111) and a Fresnel focusing device was used at the ID21 beamline at ESRF (Grenoble, France). Self-absorption effects were taken into account as the samples concentrated in manganese could not be prepared. Then, the XANES spectra were collected in the fluorescence mode. Several model compounds were used to check the accuracy of these corrections (using the code FLUO [17]), and also the accuracy of the transmission data. The energy level was calibrated with $\mathrm{KMnO}_{4}$, the energy of the $\mathrm{Mn}^{7+}$ pre-edge peak chosen was to be at $6543.6 \mathrm{eV}$. In order to extract accurate redox information, the pre-edge information was extracted following a method described in detail elsewhere for a variety of natural minerals and glasses [18], as well as for archeological samples [19].

\section{$3 \quad$ Results and discussion \\ 3.1 Ekain, Basque Country, Spain}

Three samples of manganese oxide have been characterized: one from the horse head in the entrance of the cave, the second from the bears (Fig. 1), and the last one from a natural deposit present inside the cave (Table 1). SEM observation of the "horse" sample shows the presence of a prismatic nearly pure manganese oxide, associated with quartz, clay, calcite and some iron oxides. SEM and TEM observations of the "deposit" sample and of the "bear" sample show the presence of clay and simple poorly crystallized manganese oxide. The natural deposit is composed of manganese oxide mixed with calcite, iron oxide and apatite. In the "bear" sample, quartz and calcite were found.

In these three samples, no clear electron diffraction patterns could be obtained because of their low crystallinity. To more precisely characterize the aperiodic manganese oxide structure, Mn $K$-edge XANES experiments were performed as a complementary method. Mn $K$-edge XANES spectra were obtained for the "deposit" sample and the "horse" sample (using the ID21 microfocused synchrotron beam of ESRF, Grenoble). In addition, mapping of Mn $K$-edge was performed to check the samples homogeneity.

Comparison of these spectra with our reference model database [18] enables us to identify unambiguously groutite $(\alpha-\mathrm{MnOOH})$ in both samples from the "deposit" and the "horse" (Fig. 3). Despite the fact that the Ekain natural manganese deposit and the horse painting contain the same type of manganese oxide (i.e., groutite), we must be careful about the relation between these two pigments. In fact, the associated minerals observed among these two samples are very different (cf. Table 1) and, when present, occur in various amounts. So, we cannot assert unambiguously that the paleolithic people did or did not use this deposit to extract the "horse" pigment. It is also important to stress that, to our knowledge, groutite is a relatively scarce mineral, particularly in the Spanish Basque country. Finally, the presence of this oxihydroxide suggests that the painting matter did not undergo extensive heat treatment (otherwise the hydroxide would have modified into pyrolusite, a dehydrated oxide, at more than $300^{\circ} \mathrm{C}$ ).

\begin{tabular}{|c|c|c|c|}
\hline Cave & Sample & Description & Composition \\
\hline Ekain & "Bear" & Black painting & $\begin{array}{l}\text { Simple manganese oxide with clay, } \\
\text { quartz and calcite }\end{array}$ \\
\hline Ekain & "Horse head" & Black painting & $\begin{array}{l}\text { Groutite with quartz, clay, calcite and } \\
\text { some iron oxides }\end{array}$ \\
\hline Ekain & Natural deposit & $\begin{array}{l}\text { Deposit of Mn oxide with pre- } \\
\text { historic traces of exploitation }\end{array}$ & $\begin{array}{l}\text { Groutite with clay, calcite, iron oxide } \\
\text { and apatite }\end{array}$ \\
\hline Gargas & Hand nr. 11 & $\begin{array}{l}\text { Black negativ hand from } \\
\text { the pannel of the "Entrance } \\
\text { Gallery" }\end{array}$ & $\begin{array}{l}\text { Mixture of manganite, hollandite and } \\
\text { cryptomelane }\end{array}$ \\
\hline Gargas & Hand nr. 3 & $\begin{array}{l}\text { Black negativ hand from } \\
\text { the pannel of the "Entrance } \\
\text { Gallery" }\end{array}$ & $\begin{array}{l}\text { Manganite, pyrolusite and minor cryp- } \\
\text { tomelane mixed with clay and calcite }\end{array}$ \\
\hline Labastide & LBp26 & Black natural deposit & $\begin{array}{l}\text { Birnessite (1.5 wt. } \% \mathrm{Mg}, 4 \text { wt. } \% \mathrm{Ca} \text {, } \\
1.5 \mathrm{wt} \% \mathrm{~K}) \text { associated with clay, } \\
\text { quartz, calcite and titanium oxide }\end{array}$ \\
\hline Labastide & LBp44 & $\begin{array}{l}\text { Thin black layer on the rock } \\
\text { wall }\end{array}$ & $\begin{array}{l}\text { Birnessite (0.4 wt. \% } \mathrm{Mg}, 2.7 \text { wt. } \% \\
\mathrm{Ca}, 1.2 \mathrm{wt} . \% \mathrm{~K}) \text { associated with clay, } \\
\text { quartz and apatite }\end{array}$ \\
\hline Labastide & LBp45 & Filling on clay and gravel talus & $\begin{array}{l}\text { Birnessite }(0.9 \text { wt. } \% \quad \mathrm{Mg}, 2.3 \mathrm{wt} . \% \\
\mathrm{Ca}, 2.3 \mathrm{wt} . \% \mathrm{~K}) \text { associated with clay, } \\
\text { quartz and talc }\end{array}$ \\
\hline Labastide & $\begin{array}{l}\text { Black "horse" } \\
\text { sample }\end{array}$ & $\begin{array}{l}\text { Dichromatic horse with } \mathrm{Mn}- \\
\text { bearing painting }\end{array}$ & Calcite and little pyrolusite \\
\hline Combe Saunière & "Crayon" & $\begin{array}{l}\text { "Faceted" block dated from the } \\
\text { Solutrean level }\end{array}$ & Pure manganite \\
\hline Combe Saunière & "CS block" & $\begin{array}{l}\text { Raw block dated from the } \\
\text { Gravettian layer }\end{array}$ & Todorokite with minor romanechite \\
\hline
\end{tabular}

TABLE 1 Description of the archeological studied samples 


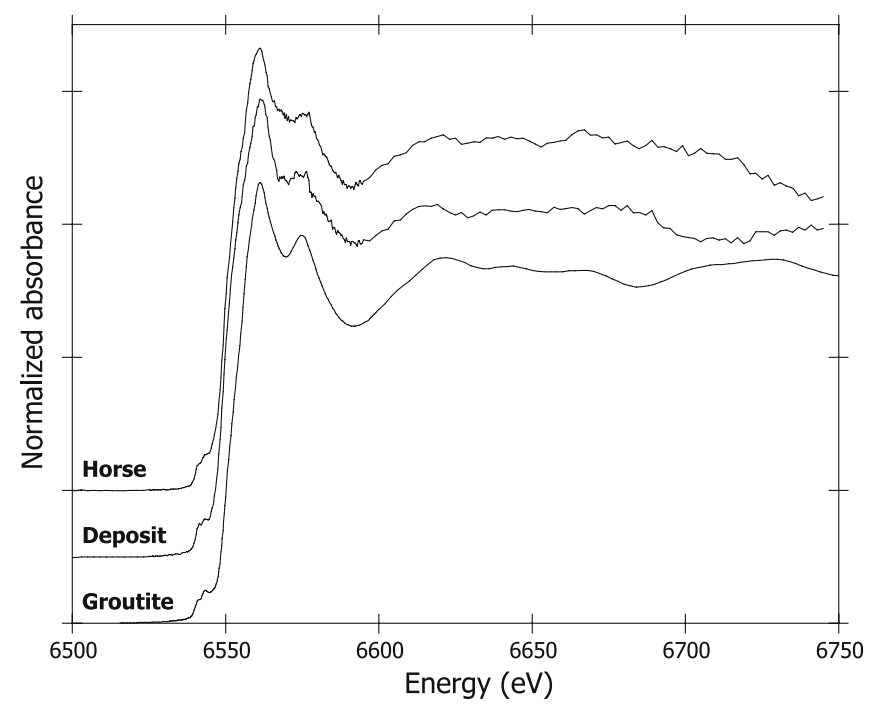

FIGURE 3 Manganese $K$-edge XANES spectra of the deposit sample, and the horse sample (data collected at ID21, ESRF) compared to the reference groutite model (data collected at SSRL, beamline 11-2)

\section{Gargas, Hautes-Pyrénées, France}

Several black negative hands have been sampled in order to compare their painting matter and to identify the nature of the pigments. Some of them were realized with charcoal ("Hand Sanctuary"), and the other ones with manganese oxides ("Entrance Gallery") [7]. Two samples of black hands realized from manganese oxide were made on the Hand nr. 11 and on the Hand nr. 3 from the same panel (Entrance Gallery) (Table 1).

The pigment of Hand nr. 11 is composed of a mixture of small manganite sheets (thickness above $250 \mathrm{~nm}$ ) and of columnar forms (ca. 200 by $600 \mathrm{~nm}$ ) of hollandite (12 wt. \% Ba) and cryptomelane (4 wt. \% Ba, 8 wt. \% K), as identified by TEM. This pigment was used raw without any extender (i.e., a mineral added to the pigment to modify its mechanical properties without changing the color). The painting matter from Hand nr. 3 contains a mixture of manganese oxide and natural mixed minerals, calcite and little clay. TEM enables us to identify the manganese oxides, thanks to their morphology and their electron diffraction pattern. Manganite $(\gamma-\mathrm{MnOOH})$ and pyrolusite $\left(\beta-\mathrm{MnO}_{2}\right)$ are the main component of this pigment. Minor amounts of cryptomelane $\left((\mathrm{K}, \mathrm{Ba}) \mathrm{Mn}_{8} \mathrm{O}_{16} \bullet\right.$ $x \mathrm{H}_{2} \mathrm{O}$ ) was also identified thanks to the thin prismatic crystals (columnar forms about $700 \mathrm{~nm}$ by $50 \mathrm{~nm}$ ).

From the above information, one can evidence two different "pots" (painting matter characterized by the identity, texture, morphology, grain size and impurities of the pigment [20]) which were used to paint two close hands. It reveals then two different times of realization or of preparation of the painting matter.

The discovered mixtures of various manganese oxides raise the question of the origin of these mixtures: natural or anthropic? Manganite and hollandite have different thermogeochemical stabilities ("metallogenetic"). Manganite is a rare mineral, always found in low temperature hydrothermal veins. On the contrary, hollandite and cryptomelane are high temperature minerals of metamorphic origin. Consequently, only a very few geological locations show these minerals associated (as in Dambach-la-Ville, Alsace or Haut-Poirot, Vosges, France) [21]). Consequently, the consideration of a common origin for both minerals is less plausible. So we should instead propose a deliberate ("anthropic") or an accidental mixture of manganese oxides prepared by paleolithic people to explain the cohabitation of both phases.

\subsection{Labastide, Hautes-Pyrénées, France}

The samples from Labastide are three black natural deposit samples, described in Table 1, which might have been used as a pigment ore. The first one (LBp26) is a deposit found between a stalagmitic layer and the rock wall. The sample LBp44 comes from a thin black layer on the rock wall. The last one (LBp45) was sampled from a filling on clay and gravel talus. All samples present a low crystallinity manganese oxide, mixed with clay and quartz (Fig. 4a). However, each of these sample contains some significant amounts of three particular minerals: titanium oxide (rutile for LBp26), apatite $\left(\mathrm{Ca}_{10}\left(\mathrm{PO}_{4}\right)_{6-x}\left(\mathrm{CO}_{3}\right)_{x}(\mathrm{OH})_{2}\right.$ for $\mathrm{LBp} 44)$ and talc $\left(\mathrm{Mg}_{3}\left[\mathrm{Si}_{4} \mathrm{O}_{10}(\mathrm{OH}, \mathrm{F})_{2}\right]\right.$ for $\left.\mathrm{LBp} 45\right)$.

No specific morphology could be observed in any of these samples by SEM and TEM that could suggest a heating treatment. Also, electron diffraction evidenced quasi amorphous manganese oxides (Fig. 4a).

An Mn $K$-edge XANES spectrum was collected for each sample as well as a mapping of Mn $K$-edge (ESRF, Grenoble) (Fig. 4b). The inhomogeneous repartition of manganese on the map (grey contrast) is in correlation with the microscopic observation. The spectra present similarities and are in good agreement with that for birnessite (SSRL, California). The pre-edge centroid position corresponds to manganese in a mixed redox state (between IV and II), that is in correlation with the layer structure of birnessite. The Particle Induced X-ray Emission (PIXE) analysis (no-invasive method using the extracted $3 \mathrm{MeV}$ protons beam of AGLAE, C2RMF, Paris) show the presence of more than $2.7 \mathrm{wt} . \% \mathrm{Ca}, 1.2 \mathrm{wt} . \% \mathrm{~K}$ and only $0.4 \mathrm{wt}$. \% Mg in the sample LBp44. The birnessite present in the deposit LBp26 is enriched in $\mathrm{Ca}(4 \mathrm{wt} . \%)$ and contains $1.5 \mathrm{wt}$ \% of $\mathrm{Mg}$ and $\mathrm{K}$. For LBp45, same proportion of $\mathrm{Ca}$ and $\mathrm{K}$ was detected (2.3 wt. \%) and only 0.4 wt. \% $\mathrm{Mg}$ is present (cf. Table 1).

So far, the presence of birnessite (as encountered in Labastide) has never been reported in rock art pigments, despite its widespread occurrence in many number of supergenous environments [10]. In the case of the cave of Labastide, the geological formation is favorable to microorganism activity, able to oxidize the $\mathrm{Mn}^{2+}$ ions contained in the clay (as in desert varnishes $[22,23])$. In fact, the concretionary texture of the birnessite-rich materials together with their poor fixating properties on the wall rock confirm that these materials appeared post painting, and possibly by microbial activity.

Black (Mn-bearing) painting samples from the Labastide dichromatic horse figure have been analyzed to explore the possibility of the use of a natural manganese deposit (located inside the cave or in a related geological site in this area) as a pigment source. In fact, the "horse" sample contains a number of calcite grains but very little pyrolusite (identified by TEM) as pigment. So, paleolithic men didn't use a local 


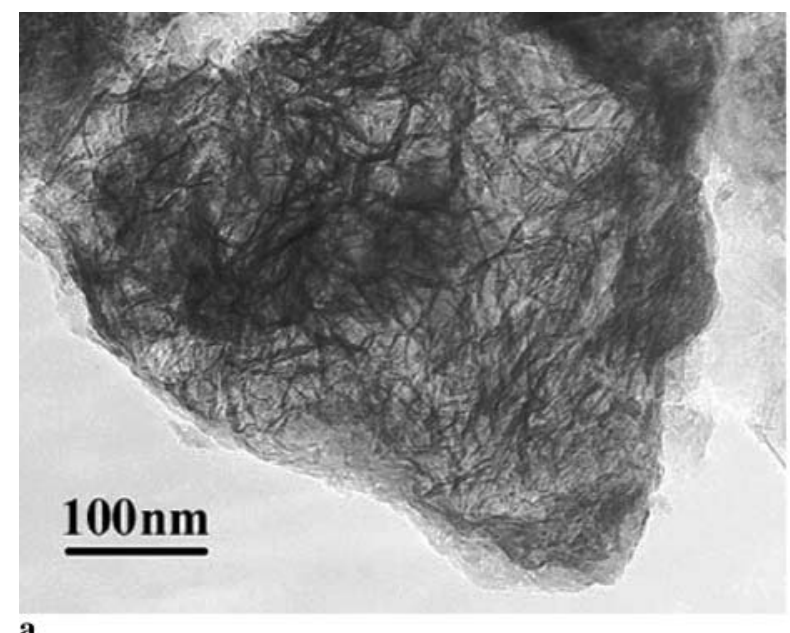

FIGURE 4 (a) TEM micrograph of non crystalline manganese oxide from the deposit of Labastide (LBp45), (b) XANES mapping and manganese $K$-edge XANES spectra of deposit sample LBp45 (data collected at ID21, ESRF) and the reference birnessite model (data collected at SSRL, beamline 11-2)

a

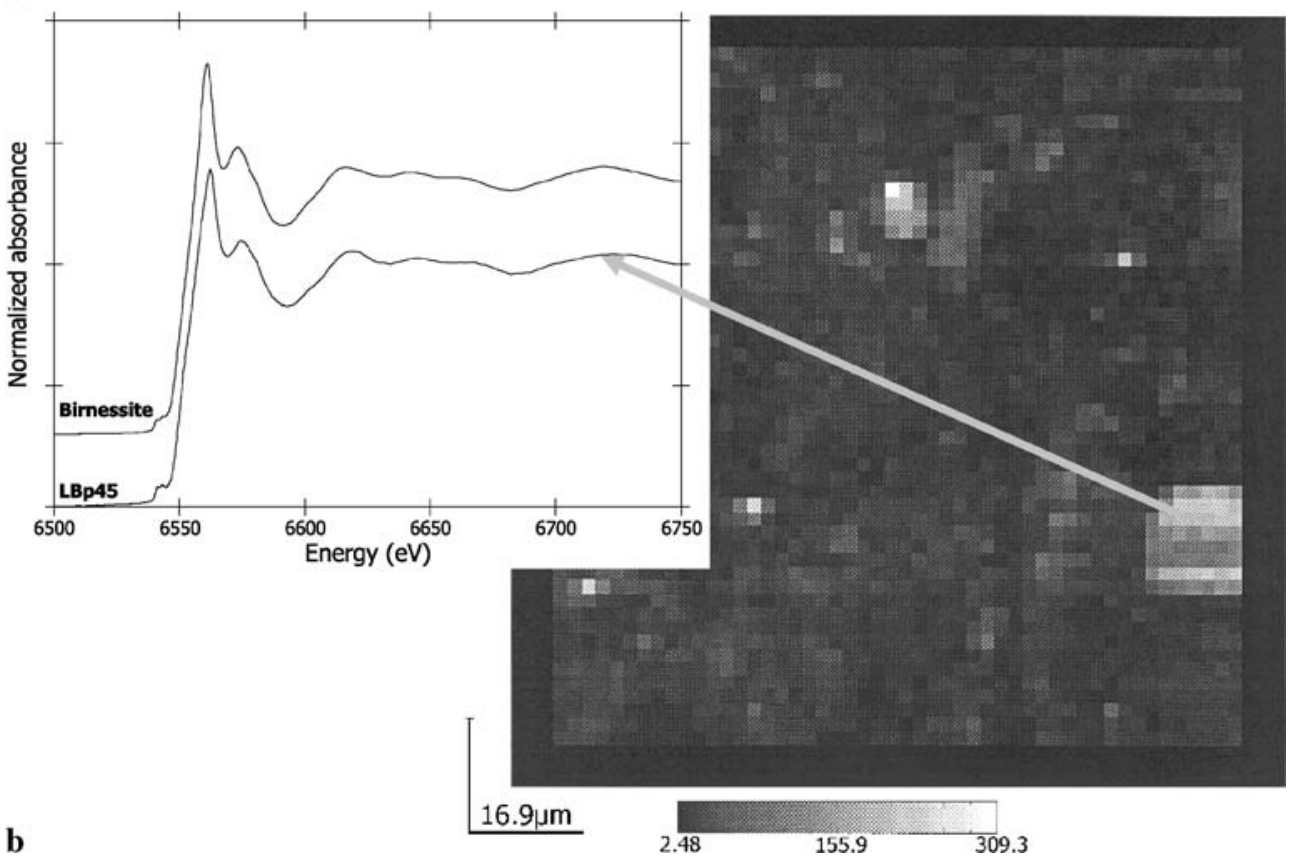

source of manganese oxide to extract the painting matter, perhaps owing to the poor fixating properties.

\subsection{Combe Saunière, Dordogne, France}

Among the forty four black blocks coming from the various layers of the settlement of Combe Saunière that were studied, two were selected to be more precisely analyzed: the so-called "crayon" (the only "faceted" block found (Fig. 5a); dated from the Solutrean level), and the "CS block" with homogeneous and porous matter (Gravettian layer).

The "crayon" is only composed of manganite (as small plaques observed by TEM), without any extender. The second block consists of agglomerated leaves of manganese oxide containing few percent of barium, potassium, calcium, sodium and magnesium, which was identified as todorokite by TEM (Fig. 5b). Minor amounts of columnar forms of romanechite were also found. The "CS block" is then nearly pure todorokite, a mineral always identified in pigments, up to now, in small quantities and naturally mixed with other manganese oxides [11].
Thanks to microscopic observation at various scales of these two blocks, the homogeneity and purity of the each gathered mineral were checked. So, we can conclude that natural materials have been used raw without any extender or heattreatment in order to transform the properties of manganese oxides.

These two minerals (manganite and todorokite) originate from very different metallogenic conditions of formation, suggesting indirectly, a large variety of origins for the raw materials used as pigment in this area. We also note that no manganite outcrop is known in this all area (the closest known occurrences of manganite are located a few hundred kilometers south, in the Pyrénées mountains, near Vicdessos/VieilleAure, a manganese metallogenetic area in Ariége).

\section{4}

\section{Conclusion}

Various manganese oxides have been identified as black prehistoric pigment, such as pyrolusite, romanechite, hollandite, cryptomelane, todorokite, manganite and groutite. 

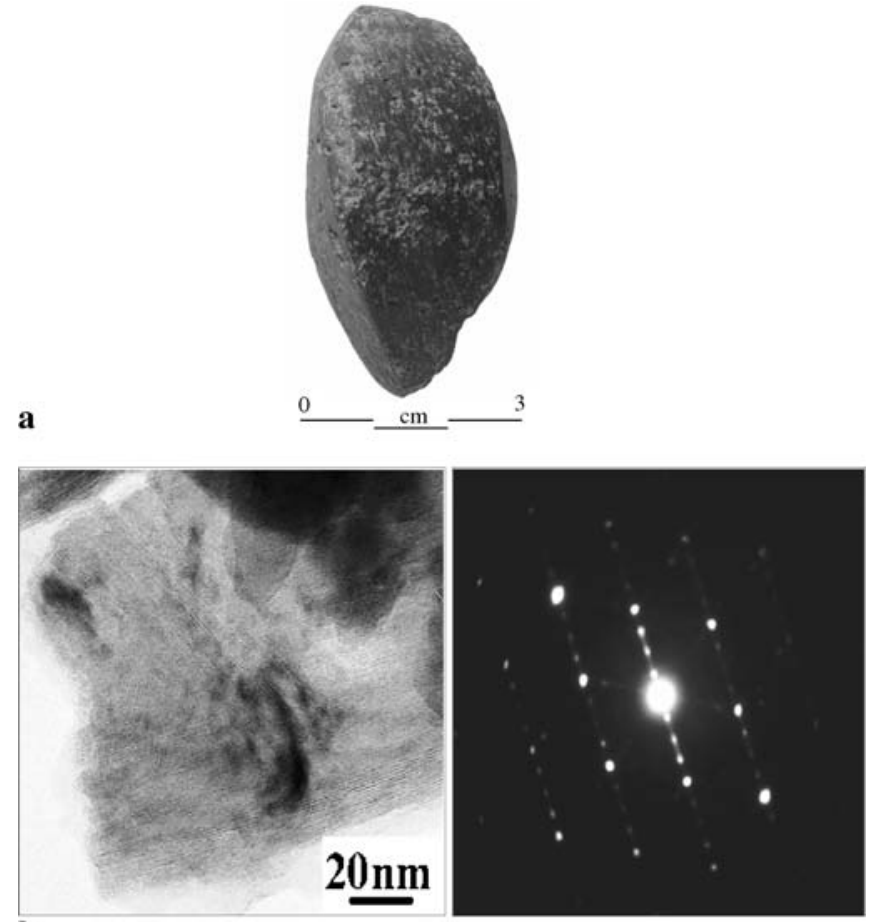

b

FIGURE 5 (a) Black "crayon" of Combe Saunière, the only faceted block Marcillaud J.G. (b) G17C20 block of Combe Saunière: TEM micrograph of todorokite crystals identified by electron microdiffraction pattern ([001] zone axis single crystal)

For the first time, manganite has been identified under two mineral associations: (1) mixed with other oxides in painting matter from the cave of Gargas, and (2) relatively pure and massive in the black faceted block ("crayon") of Combe Saunière. Also, groutite is the pigment used for the horse head at the entrance of the cave of Ekain. Intriguingly, these minerals are very rare (if not unknown) nowadays in the south west region of France, where these paintings were realized. Even if exploitable mineral deposits are few, small manganese ores can be found in many places in the Pyrénées in enough quantity to realize some paint. Either the source of raw material is exhausted or lost, or some unsuspected trading routes have to be taken into account to explain the presence of these minerals in the painting material.

It is known that paleolithic people enhanced the properties of pigment with the use of extenders [7]. Thanks to a combined TEM and XANES microstructural study, we may conclude that these people composed their own painting matter with several manganese oxides, in particular relatively "high temperature" manganite mixed with a more exogeneous todorokite. Therefore, it seems that they ground together black pigments from very different ores.

ACKNOWLEDGEMENTS The authors wish to thank Françoise Pillier (LISE, UPR 15 CNRS, Paris) and Marie-Pierre Pomiès (C2RMF, Paris) respectively for their help in TEM and XRD analysis. We thank also John R. Bargar and G.E. Brown Jr. (Stanford Synchrotron Radiation Laboratory, Stanford, California) who gave us access to synchrotron beams. Thanks to Martine Regert (CNRS, C2RMF) for the helpful discussions.

The help of archeologists Jean-Michel Geneste (SRA, Aquitaine, Bordeaux), Jean Pierre Chadelle (SDA, Dordogne), Jesus Altuna (Société des Sciences Aranzadi, Donostia, Spain) and Robert Simonnet (Laboratoire de Préhistoire, Toulouse), who permitted the study of samples respectively from the sites of Combe Saunière, Ekain and Labastide, is gratefully acknowledged.

\section{REFERENCES}

1 E. Carthailhac, L'Anthropologie 16, 41 (1902)

2 H. Moissan, Compte-rendu de l'Académie des Sciences 134, 1536 (1902)

3 H. Moissan, Compte-rendu de l'Académie des Sciences 136, 144 (1903)

4 C. Couraud, A. Laming-Emperaire, Lascaux inconnu, Ed. par LeroiGourhan, A. Allain, J. Paris: CNRS (1979) p. 153

5 J. Clottes, M. Menu, P. Walter, Bulletin de la Société Préhistorique Française 87, 170 (1990)

6 M.P. Pomiès, M. Menu, C. Vignaud, Archaeometry 41, 185 (1999)

7 A. Clot, M. Menu, P. Walter, L'Anthropologie 99, 221 (1995)

8 R. Simonnet, Congrès National des Sociétés Historiques et Scientifiques, 118th, Pau, 341 (1993)

9 J.M. Geneste, H. Plisson, Gallia Préhistoire 29, 9 (1986)

10 J.E. Post, Catena Suppl. 21, 51 (1992)

11 E. Chalmin, phD, University of Marne la Vallée (2003) Free PDF version at http://pelleas.univ-mlv.fr/document/UMLV-2004-000148-PDF (in French)

12 N. Aujoulat, E. Chalmin, C. Vignaud, J.M. Geneste, M. Menu, Actes du colloque des 10èmes journées d'études de la SFIIC, 5 (2002)

13 E. Chalmin, C. Vignaud, M. Menu, Appl. Phys. A 79, 187 (2004)

14 D.C. Smith, M. Bouchard, M. Lorblanchet, J. Raman Spectrosc. 30, 347 (1999)

$15 \mathrm{M}$. Lorblanchet, La maison des sciences de l'homme (Documents d'archéologie française, Paris 2001)

16 J. Vouvé, J. Brunet, F. Vouvé, Stud. Conserv. 37, 185 (1992)

17 D. Haskel, www.aps.anl.gov/xfd/people/haskel. (1999)

18 E. Chalmin, F. Farges, G.E. Brown Jr., Am. Mineral. (submitted)

19 F. Farges, E. Chalmin, C. Vignaud, I. Pallot-Frossard, J. Susini, J. Bargar, G.E. Brown Jr., M. Menu, Physica Scripta, T115 (2005)

20 M. Menu, P. Walter, Nucl. Instrum. Methods Phys. Res. B 64, 547 (1992)

21 A. Witter, J.R. Journée, Ein Führer zu über 40 Fundstellen.- Aufschluss 48 (von Loga, Köln, 1997) p. 64

22 D.A. Mc Keown, J.E. Post, Am. Mineral. 86, 701 (2001)

23 J.R. Bargar, B.M. Tebo, J.E. Villinski, Geochim. Cosmochim. Acta 64, $2775(2000)$ 